\title{
IMPACT OF WATER QUALITIY ON BARLEY VARIETIES, SOIL PROPERTIES AND THEIR CONTENTS OF HEAVY METALS
}

\author{
Atwa. A. A. E. ${ }^{*}$; N.I. Talha; E.S. EL-Gizawy and kh. A. Amer** \\ *Soils, Water and Environment Research Institute Agric. \\ Res.center,Giza,Egypt. \\ ${ }^{\star *}$ Barley Res. Dept., Field Crops Res. Institute, Agric. Res. Center, Giza, \\ Egypt.
}

\begin{abstract}
Two Lyzimeter experiments were conducted at Sakha Agricultural Research Station, Kafr El-Sheikh, Egypt, for two seasons, 2010/2011 and 2011/2012 Lyzimeters $(100 \times 70 \times 90 \mathrm{~cm})$ were filled with clayey soil and irrigated with three water treatments since twenty three years ago.

The present study aimed to investigate the effect of irrigation water quality for long-term on productivity of four barely varieties (Giza123, 124, 126 and Giza129). Three irrigation water qualities; Nile water $\left(W_{1}\right)$, polluted drainage water $\left(W_{3}\right)$ and mixed water; $W_{2}\left(50 \% W_{1}+50 \% W_{3}\right)$ used for irrigation to study its effects on barely contents from four heavy metals $\mathrm{Ni}, \mathrm{Cd}, \mathrm{Pb}$ and $\mathrm{Cu}$ and some soil characteristics. A split-plot design with four replicates was used where, water treatments and varieties were allocated to main and sub-plots, respectively.

The obtained results showed that:

- Using poor water quality for irrigation increased ECe, SAR, soluble cations and anions in soil paste extract and DTPA extractable heavy metals in soils $(\mathrm{Cu}, \mathrm{Ni}, \mathrm{Cd}$ and $\mathrm{Pb}$ ) than that of mixed or good water quality.

- Highly significant differences of yield and yield components among barely varities were found due to irrigation water treatments and its contents of heavy metals.

- Straw heavy metals content were higher than that of grains.

- The results showed that Giza 123 was more tolerant variety to drainage and mixed water and its lower or higher contents of $\mathrm{Ni}, \mathrm{Pb}$ and $\mathrm{Cu}$.

- No significant differences were found among $\mathrm{Cd}$ content for all studied barley varieties.

- The heavy metals content of barley varieties from can be arranged as follow:

With $\mathrm{Pb}: \mathrm{v}_{2}<\mathrm{v}_{3}<\mathrm{v}_{1}<\mathrm{v}_{4}$

With Cu: $v_{1}<v_{2}<v_{3}<v_{4}$

With Ni: $v_{2}<v_{1}<v_{3}<v_{4}$

Keywords: Water quality, productivity, heavy metals, barley varieties, soil characteristics.
\end{abstract}

\section{INTRODUCTION}

Pollution is defined as any change in physical, chemical or biological conditions of the environment which may harmfully affect the quality of human life including effects upon animals and plants.

The untreated industrial drainage waters contain little or more amount of heavy metals, which may cause enhancement of their level in the Nile and/or agricultural drainage water when they mixed. 
Atwa. A. A. E. et al.

A recent study showed a remarkable increase in levels of heavy metals in some Egyptian soils (especially soils lies in the extreme North Delta) in addition appreciable amount of these metals are found in vegetation, water bodies and aquatic organisms in western and middle areas of the Nile Delta (Zein et al.1998, El-Sanafawy, 2002).

Use of low quality water in irrigation could be an important consideration when the disposal is being planned in arid and semi arid regions. Using drainage water in irrigation caused high increase in EC and SAR of saturated soil paste extract (Omar et al., 2001). Meanwhile, using drainage water in irrigation significantly increase the total and DTPA extractable heavy metals compared with Nile water (Zein et al., 2002).

Once the ions have been absorbed through the roots or straw and have been transported to the xylem vessels there is the possibility of movement throughout the whole plants. The rate and extent of movement within plants depend on the metal concerned, the plant organ and the age of plant (Chaney and Giordano, 1977). Mn, Zn, Cd, B, Mo and $\mathrm{Cu}$ were classified as intermediate and $\mathrm{Cr}, \mathrm{Pb}$ and $\mathrm{Hg}$ were translocated to least extent The heavy metal pollution of soils is a current environmental problem.A number of factors including climate, atmospheric deposition, the nature of soil on which the plant is grown and the maturity degree of plant at time of harvesting influence the concentration of heavy metals on and within plants (voutsa et al. 1996 and Lake et al.1984). Heavy metal contents of food plants can be affected by the anthropogenic factors such as the application of fertilizers, sewage sludge or irrigation with waste waters (Devkota and Schmidt, 2000 and frost and ketchum 2000). Heavy metal contamination of agricultural soils can pose long - term environmental problems and are not without health implications (Ferguson 1990). In conclusion, increasing industrialization and urbanization have not only degradation but also caused the contamination of our precious food resources. During recent years, studies on toxic effects of heavy metals especially $\mathrm{Cd}$, on crop plants are being received considerable attention (Boussamo et al, 1999). Translocation of Cd from root to shoot has been studied in several plant species, showing that it is likely to occur via the xylem and to be driven by leaf transpiration (Hart et al.1998). The studies on the determination of metal concentration in plant species are not important only for their translocation to food chain, but also examination of the soil remediation by phytoextraction of toxic metals. Throughout all countries, the extent of contamination of irrigation water with $\mathrm{Cd} \mathrm{Pb}$ and $\mathrm{Ni}$ were not being able to be determined due to its increasing usage as well as production.

The objectives of the present work are to assess the effect of irrigation water quality for long-term on productivity, heavy metals contents of barley varieties and some soil characteristics.

\section{MATERIALS AND METHODS}

Two lyzimeter experiments were carried out at Sakha Agricultural Research Station, Kafr El-Sheikh, Egypt, for two seasons 2010/2011 and 
$2011 / 2012$ to study the effect of irrigation water quality for long -term on the productivity of four barley varieties, (Giza123 (v1),Giza124(.v2), Giza126(v3) and Giza129(v4)) and the content of their, , grains and straw of heavy metals; $\mathrm{Pb}, \mathrm{Cd}$, $\mathrm{Ni}$ and $\mathrm{Cu}$.

The study was conducted in concrete Lyzimeters $(100 \times 70 \times 90 \mathrm{~cm})$ filled with clayey soil since 1987.

The four barley varieties were planted on 11 November in two seasons at $60 \mathrm{~kg} / \mathrm{fed}$.Three water treatments were used for irrigation; Nile water $W_{1}$ polluted drainage water $W_{3}$ and mixed water $W_{2} ;\left(50 \% W_{1}+50 \%\right.$ $\mathrm{W}_{3}$ ). Some characteristics of the used irrigation water are presented in Table 1.

The treatments were incorporated in a split -plot design with four replicates. Irrigation treatments and varieties were allocated the main and sub plots, respectively. Phosphorus was applied as super phosphate $\left(15.5 \% \mathrm{P}_{2} \mathrm{O}_{5}\right)$ in one dose before sowing at rate of $15.5 \mathrm{Kg} \mathrm{P}_{2} \mathrm{O}_{5} /$ Fed. Nitrogen was applied as urea $(46.5 \mathrm{~N} \%)$ at rate of $60 \mathrm{Kg} \mathrm{N} / \mathrm{fed}$. in two dose and potassium fertilizer was added in the form of potassium sulphate ( $48 \%$ $\mathrm{K}_{2} \mathrm{O}$ ) at rate of $24 \mathrm{~kg} \mathrm{~K} \mathrm{~K}_{2} \mathrm{O} /$ fed. after one month of planting. All other agronomic practices were followed as recommended. Plants were harvested in 15 May, and straw and grains yields were weighted in $\mathrm{Kg} / \mathrm{fed}$. Representative seed and straw, were collected for analysis, weighted technique was used for samples digestion as described by Chapman and Pratt (1961). Soil samples were taken from each lyzimeter before planting and after harvesting, for chemical analysis; total soluble salts, soluble cations $\&$ anions in soil paste extract were determined according to Richards (1969). Soil samples were DTPA extracted and $\mathrm{Pb}, \mathrm{Cd}, \mathrm{Ni}$ and $\mathrm{Cu}$ were determined using an Atomic Absorption Spectrophotometer. Soil chemical analysis DTPA exctect before sowing and after harvesting (according to Lindsay and Norvell, 1978) are presented in Table (2). Statistical analysis was carried out using Irristat- Software, Computer Program.

Table (1): Chemical characteristics of Nile and drainage water used for irrigation during the two seasons.

\begin{tabular}{|c|c|c|c|c|c|c|c|c|c|c|c|c|}
\hline \multirow[b]{2}{*}{ Water qualities } & \multirow{2}{*}{\begin{tabular}{|c|} 
EC, \\
dS $/ \mathrm{m}$ \\
at \\
$25^{\circ} \mathrm{c}$ \\
\end{tabular}} & \multirow[b]{2}{*}{$\mathrm{pH}$} & \multicolumn{4}{|c|}{ Cation, meq/L } & \multicolumn{4}{|c|}{ Anion, meq/L } & \multirow[b]{2}{*}{$=S A R$} & \multirow[b]{2}{*}{$\begin{array}{l}\text { Water } \\
\text { class }\end{array}$} \\
\hline & & & $\mathrm{Ca}^{++}$ & $\mathrm{Mg}^{+2}$ & $\mathrm{Na}^{+}$ & $\mathrm{K}^{+}$ & $\mathrm{CO}_{3}=$ & $=\mathrm{HCO}_{3}$ & $\mathrm{Cl}^{-}$ & $\mathrm{So}_{4}=$ & & \\
\hline Nile water & 0.52 & 7.8 & 1.8 & 1.50 & 1.6 & 0.3 & - & 3.1 & 1.01 & 1.09 & 1.25 & $\mathrm{C}_{2}-\mathrm{S}_{1}$ \\
\hline $\begin{array}{l}\text { Drainage } \\
\text { water }\end{array}$ & 1.70 & 8.20 & 4.90 & .2 .6 & 9.02 & 48 & - & 3.5 & 8.3 & 5.20 & 4.65 & $\mathrm{C}_{3}-\mathrm{S}_{2}$ \\
\hline \multirow{2}{*}{\multicolumn{5}{|c|}{ Irrigation water }} & \multicolumn{8}{|c|}{ Heavy metal content (mg/L) } \\
\hline & & & & & \multicolumn{2}{|c|}{\begin{tabular}{l|l}
$\mathrm{Cu}$ \\
\end{tabular}} & \multicolumn{2}{|c|}{\begin{tabular}{c|}
$\mathrm{Ni}$ \\
\end{tabular}} & \multicolumn{2}{|c|}{ Cd } & \multicolumn{2}{|c|}{$\mathbf{P b}$} \\
\hline \multicolumn{2}{|l|}{ Nile water } & & & & \multicolumn{2}{|c|}{0.019} & \multicolumn{2}{|c|}{.0 .008} & \multicolumn{2}{|c|}{0.007} & \multicolumn{2}{|c|}{0.08} \\
\hline \multicolumn{2}{|c|}{ Drainage water } & & & & \multirow{2}{*}{\multicolumn{2}{|c|}{$\begin{array}{l}0.290 \\
0.200\end{array}$}} & \multicolumn{2}{|c|}{0.307} & \multicolumn{2}{|c|}{0.039} & \multicolumn{2}{|c|}{0.800} \\
\hline \multicolumn{2}{|c|}{ Critical limits according FAO (1989) } & & & & & & & 200 & & 010 & & .000 \\
\hline
\end{tabular}


Atwa. A. A. E. et al.

\section{RESULTS AND DISCUSSION}

\section{Nile and drainage waters evaluation:}

Chemical characteristics of Nile and drainage water used for irrigation of barley varieties are shown in Table (1) According to Richard's classification, Nile water $\left(\mathrm{C}_{2}-\mathrm{S}_{1}\right)$ medium salinity low sodicity (Richards, 1969). While, data of drainage water revealed that the water was in the class of $\left(\mathrm{C}_{3}\right.$ $\mathrm{S}_{2}$ ) high salinity and medium sodicity which can not be used for soils with restricted drainage and crop with good salt tolerance should be selected. It can be concluded that Nile water is of good quality and drainage water of poor quality for irrigation. The mixed water will be intermediate between them in relation to its chemical composition. Also data in Table (1) Showed that the studied heavy metals $\mathrm{Cd}, \mathrm{Pb}, \mathrm{Ni}$ and $\mathrm{Cu}$ content of drainage water were greater than of Nile water and higher than the critical limits, according to FAO (1989), i.e., $0.01,5.00,0.2$ and 0.2 for $\mathrm{Cd}, \mathrm{Pb}, \mathrm{Ni}$ and $\mathrm{Cu} \mathrm{mg} / \mathrm{L}$, respectively. The high heavy metal contents in drainage water could be attributed to the pollution sources of industrial and municipal wastes discharged to the drainage system. These results are in agreement with those obtained by ElMowelhi et al., (1995).

Effect of the studied irrigation water qualities on some chemical properties of clay soils:

\section{A- Soil salinity, SAR and soluble ions:}

Change in electrical conductivity of soil paste extract $(\mathrm{dS} / \mathrm{m})$ soluble cations ; $\mathrm{Ca}^{+2}, \mathrm{Mg}^{+2}, \mathrm{Na}^{+}$and $\mathrm{K}^{+}(\mathrm{meq} / \mathrm{L})$ and soluble anions; $\mathrm{HCo}_{3}^{-}, \mathrm{Cl}^{-}$and $\mathrm{SO}_{4}^{--} ;(\mathrm{meq} / \mathrm{L})$ are listed in Table (2). Comparing the mean ECe values of the studied soils, before planting and after harvesting. The data show that EC values increased from 2.95, 5.12 and $6.10 \mathrm{dS} / \mathrm{m}$ to $3.05,5.35$ and $6.56 \mathrm{dS} / \mathrm{m}$ as affected by $W_{1}, W_{2}$ and $W_{3}$ water quality treatments, respectively. SAR mean values increased from 4.46 and 6.77 to 4.79 and 6.85 as affected by $\mathrm{W}_{2}$ and $\mathrm{W}_{3}$ water treatment. The obtained data showed also, that utilization of drainage water for irrigation purposes tend to increase soluble cations and anions $\mathrm{Na}^{+}, \mathrm{Mg}^{++}, \mathrm{So}_{4}{ }^{-}$and $\mathrm{Cl}^{-}$than before planting. The data also showed that all soluble anions, $\mathrm{Cl}^{-}$and $\mathrm{So}_{4}{ }^{-}$mean values, were higher in soil irrigated with poor water quality in harmony with those obtained by Zein et al. (2012).

\section{B- DTPA- extracted heavy metals from studied soils:}

Data in Table (3) show that all values of DTPA extractable heavy metals of soils can be discendingly arranged according to the effect of water treatments as follow: $W_{3}>W_{2}>W_{1}$ before barely planting and after harvesting.

It seems that soil content of DTPA-extractable studied heavy metals has followed the sequence $\mathrm{Cu}>\mathrm{Pb}>\mathrm{Ni}>\mathrm{Cd}$. This trend was different from that found under using drainage water and mixed water $\mathrm{Pb}>\mathrm{Cu}>\mathrm{Ni}>\mathrm{Cd}$. This may be due to that some of available $\mathrm{Pb}$ changed to these findings. The obtained results are in agreement with those of Abou El-Roos et al. (1991) who found that the behaviour of $\mathrm{Cu}$ and $\mathrm{Pb}$ differ from that of $\mathrm{Cd}, \mathrm{CO}$ and $\mathrm{Ni}$ in soils irrigated with sewage effluent, they added that in $\mathrm{Cd}$, $\mathrm{Cu}$ and $\mathrm{Ni}$ metals, the percentages held in primary minerals fraction were increased with 
time on the expense of the percentage of other fractions, especially that organically complexed. Although the studied soils were still beyond the critical levels, it could be reached this point upon the continuous using of polluted drainage water.

Table (2): Soil chemical analysis before planting and after harvesting under three irrigation water quality.

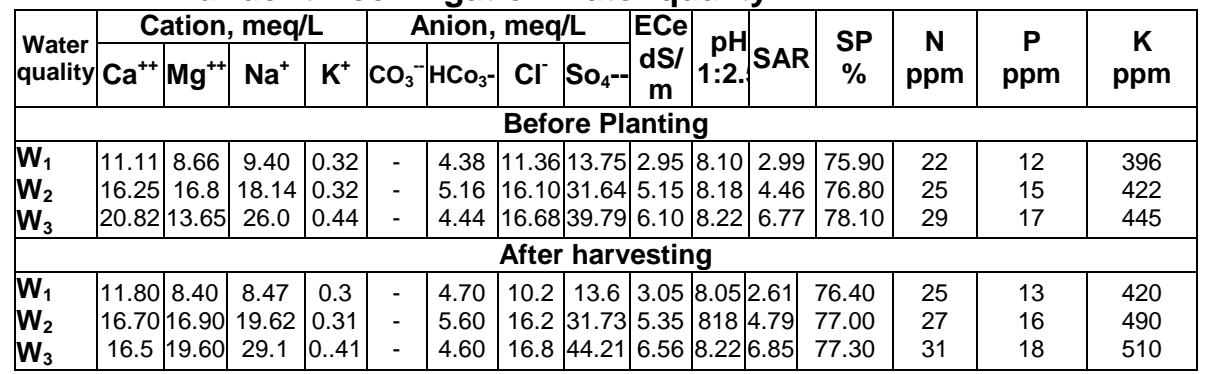

Table (3): DTPA extractable heavy metal concentrations $(\mathrm{mg} / \mathrm{kg}$ ) before planting (2010) and after harvesting (2012) barley as affected by water quality.

\begin{tabular}{|l|c|c|c|c|}
\hline \multirow{3}{*}{ Irrigation water quality } & \multicolumn{5}{|c|}{ Heavy metal content ( mg/kg soil) } \\
\cline { 2 - 5 } & $\mathbf{C d}$ & $\mathbf{N i}$ & $\mathbf{P b}$ & $\mathbf{C u}$ \\
\cline { 2 - 5 } & \multicolumn{5}{|c|}{ Before planting (2010) } \\
\hline $\mathbf{W}_{\mathbf{1}}$ & 0.100 & 1.82 & 4.01 & 6.20 \\
$\mathbf{W}_{2}$ & 0.170 & 2.02 & 9.10 & 6.80 \\
$\mathbf{W}_{3}$ & 0.180 & 2.72 & 11.10 & 7.80 \\
\hline & \multicolumn{5}{|c|}{ After harvesting (2012) } \\
\hline $\mathbf{W}_{1}$ & 0.110 & 1.85 & 4.90 & 6.90 \\
$\mathbf{W}_{2}$ & 0.172 & 2.20 & 9.20 & 6.90 \\
$\mathbf{W}_{3}$ & 0.185 & 2.50 & 11.90 & 8.45 \\
\hline
\end{tabular}

Effect of water Quality on yield and yield components:

Data in Table (4) show that the seed yield ardb/fed of barley were significantly affected with barley varieties. The higher mean seed yields (18.66, 18.16), (17.52, 17.24) and (, 17.80, 17.14) ardb/fed were obtained with $W_{1}, W_{2}$ and $W_{3}$ in the two seasons, respectively. In same Table data show that the straw yield $\mathrm{kg} / \mathrm{fed}$ of barely were significantly affected by barley varieties, the higher mean of straw yield of Giza 126 of two seasons under three of water qualities. In same Table data show that the weight of spike (gm)of barely were significantly affected by barley varieties, the higher mean of weight of spike of Giza 124 of two seasons under the Nile water but Giza 126 under mixed and drainage water of tow seasons. 
Atwa. A. A. E. et al.

Table (4): Effect of irrigation water treatments on yield and yield components of the tested barley varieties in two seasons.

\begin{tabular}{|c|c|c|c|c|c|c|}
\hline \multirow{3}{*}{ Varieties } & \multicolumn{6}{|c|}{$\begin{array}{l}\text { Irrigation water treatments } \\
\end{array}$} \\
\hline & \multicolumn{3}{|c|}{ First season } & \multicolumn{3}{|c|}{ Second season } \\
\hline & $\mathrm{W}_{1}$ & $\mathrm{~W}_{2}$ & $\mathbf{W}_{3}$ & $\mathrm{~W}_{1}$ & $\mathrm{~W}_{2}$ & $\mathbf{W}_{3}$ \\
\hline \multicolumn{7}{|c|}{ Seed yield (ardb/fed) } \\
\hline Giza123 & $17.03 \mathrm{ab}$ & $16.63 \mathrm{~b}$ & $19.60 \mathrm{~b}$ & $16.33 \mathrm{~b}$ & $16.12 \mathrm{~b}$ & $19.11 \mathrm{~b}$ \\
\hline Giza124 & $18.47 \mathrm{a}$ & $15.83 \mathrm{~b}$ & $16.22 \mathrm{c}$ & $18.51 \mathrm{a}$ & $15.34 b$ & $15.77 \mathrm{c}$ \\
\hline Giza126 & $16.41 \mathrm{~b}$ & $22.60 \mathrm{a}$ & $22.47 \mathrm{a}$ & $15.55 b$ & $21.74 \mathrm{a}$ & $21.41 \mathrm{a}$ \\
\hline Giza129 & $16.70 \mathrm{~b}$ & $15.43 \mathrm{~b}$ & $12.92 \mathrm{~d}$ & $16.25 \mathrm{~b}$ & $15.75 b$ & $12.28 \mathrm{~d}$ \\
\hline Means & 18.66 & 17.92 & 17.80 & 18.16 & 17.24 & 17.14 \\
\hline \multicolumn{7}{|c|}{ Straw (kg/fed) } \\
\hline Giza123 & $3465 b$ & 3503.3b & $3833.3 b$ & 3560.3b & $3660.4 b$ & 4063.2b \\
\hline Giza124 & $3553.3 b$ & $3390 c$ & 2950d & $3637.8 b$ & $3540.4 c$ & $3127 d$ \\
\hline Giza126 & 3803.3a & 3903.3a & $4233 a$ & $3924 a$ & 4.084.4a & $4487 a$ \\
\hline Giza129 & $3078 \mathrm{c}$ & $3080 d$ & 3142c & $3263 c$ & $3211.8 d$ & $3330 \mathrm{c}$ \\
\hline Means & 3987.25 & 3614.15 & 3539.58 & 3483.58 & 3824.25 & 3751.75 \\
\hline \multicolumn{7}{|c|}{ Weight of spike (gm) } \\
\hline Giza123 & $1.012 b$ & $1.077 \mathrm{~b}$ & $1.237 \mathrm{~b}$ & $1.011 \mathrm{~b}$ & $1.070 \mathrm{~b}$ & $1.241 \mathrm{~b}$ \\
\hline Giza124 & $1.227 \mathrm{a}$ & $1.050 \mathrm{~b}$ & $1.030 c$ & $1.220 \mathrm{a}$ & $1.050 \mathrm{~b}$ & $1.04 c$ \\
\hline Giza126 & $1.011 \mathrm{c}$ & $1.453 a$ & $2.160 a$ & $1010 c$ & $1.323 a$ & $2.150 \mathrm{a}$ \\
\hline Giza129 & $1.013 b$ & $1.060 \mathrm{~b}$ & $1.230 \mathrm{~b}$ & $1.013 b$ & $1.070 \mathrm{~b}$ & $1.220 \mathrm{~b}$ \\
\hline Means & 1.066 & 1.160 & 1.410 & 1.064 & 1.128 & 1.413 \\
\hline
\end{tabular}

\section{Heavy metals contents:}

Data in Table (5) show that the studied heavy metals $\mathrm{Cd}, \mathrm{Pb}, \mathrm{Ni}$ and $\mathrm{Cu}$ content of barley plant under drainage water were greatest than that of Nile water and mixed water. This could be attributed to the pollution sources of industrial (oil and soap factory) and municipal wastes discharged to the drainage system. These results are in agreement with those obtained by Zein et al. (2002) and El-Mowelhi et al. (1995).

Table, 5 illustrate that the influence of water quality on the studied heavy metals means concentration in straw and grains. On barley varieties especially with irrigated by drainage water $\left(\mathrm{W}_{3}\right)$ were as the following order:

In both grains and straw were $\mathrm{Cu}>\mathrm{Pb}>\mathrm{Ni}>\mathrm{Cd}$.

Table (5) reveals also that the highly significant effects of water quality $\left(\mathrm{W}_{1}, \mathrm{~W}_{2}\right.$ and $\left.\mathrm{W}_{3}\right)$ especially with $\mathrm{Ni}$ and $\mathrm{Pb}$.

The distribution of $\mathrm{Cu}$ within plants is highly variable within roots $\mathrm{Cu}$ is associated mainly with cell wall and its largely mobile.

Dunman et al. (1991) found that the concentration of $\mathrm{Ni}$ in plants, generally, reflects the concentration of the element in the soil, although the relationship is clearly more directly related to the concentration of soluble ions of $\mathrm{Ni}$ and rate replenishment of this mobile pool. As $\mathrm{Ni}$ is easily mobile in plant, berries and seeds are reported to contain elevated Ni concentration (Kabata-Pendias, 2000).

Cadmium values (Table, 5 ) of seeds indicated that $\mathrm{Cd}$ has the lowest values in all studied heavy metals. This conclusion are in agreement with Alloway (1995) who found that the uptake of $\mathrm{Cd}$ decreased when $\mathrm{pH}$ was increased, barely showed a similar response.

Page et al. (1981) found that relative excess of $\mathrm{Cu}, \mathrm{Ni}$ and $\mathrm{Mn}$ can reduce uptake of $\mathrm{Cd}$ by plants. The $\mathrm{Cd}$ in plants is relatively very mobilize, 
although the translocation of $\mathrm{Cd}$ through the plant tissues may be restricted because $\mathrm{Cd}$ is easily held mainly in exchange sites of active compounds located in the cell walls (Cunningham et al., 1975).

Table (5): Effect of water treatments on heavy metals content $(\mathrm{mg} / \mathrm{kg})$ of grains and straw barley varieties (Mean of two seasons) and translocation coefficient (TC\%)

\begin{tabular}{|c|c|c|c|c|c|c|c|c|c|c|c|c|}
\hline \multirow{4}{*}{ 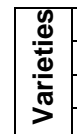 } & \multicolumn{12}{|c|}{ Heavy metals content (mg/kg dry Wight) } \\
\hline & \multicolumn{3}{|c|}{$\mathrm{Cu}$} & \multicolumn{3}{|c|}{$\mathrm{Ni}$} & \multicolumn{3}{|c|}{ Cd } & \multicolumn{3}{|c|}{ pb } \\
\hline & $\mathrm{W}_{1}$ & $\mathbf{W}_{2}$ & $\mathbf{W}_{3}$ & $\mathbf{W}_{1}$ & $\mathbf{W}_{2}$ & $\mathbf{W}_{3}$ & $\mathbf{W}_{1}$ & $W_{2}$ & $\mathbf{W}_{3}$ & $\mathbf{W}_{1}$ & $W_{2}$ & $\mathbf{W}_{3}$ \\
\hline & \multicolumn{12}{|c|}{ Grains } \\
\hline $\mathbf{V}_{1}$ & $17 a$ & $18 a$ & $20 \mathrm{~b}$ & $0.14 b c$ & $0.41 \mathrm{c}$ & $0.61 \mathrm{c}$ & $0.01 b$ & $0.03 a b$ & $0.05 a b$ & $6.7 \mathrm{c}$ & $8.0 \mathrm{~b}$ & $7.9 b$ \\
\hline$V_{2}$ & $12 b$ & $19 a$ & $24 \mathrm{a}$ & $0.12 \mathrm{c}$ & $0.66 \mathrm{a}$ & $0.78 \mathrm{~b}$ & $0.03 a$ & $0.04 a$ & $0.06 \mathrm{a}$ & $8.2 \mathrm{a}$ & $8.5 \mathrm{a}$ & $9.0 \mathrm{a}$ \\
\hline$v_{3}$ & $9 \mathrm{c}$ & $11 \mathrm{c}$ & $21 \mathrm{~b}$ & $0.29 a$ & $0.46 \mathrm{~b}$ & $0.93 a$ & $0.02 a b$ & $0.03 a b$ & $0.05 a b$ & $7.4 \mathrm{~b}$ & $7.8 \mathrm{~b}$ & $7.6 \mathrm{~b}$ \\
\hline \multirow[t]{2}{*}{$V_{4}$} & $6 \mathrm{~d}$ & $14 \mathrm{~b}$ & $18 \mathrm{c}$ & $0.15 b$ & $0.25 d$ & $0.95 \mathrm{a}$ & $0.01 b$ & $0.02 b$ & $0.04 b$ & $6.2 \mathrm{~d}$ & $6.3 \mathrm{c}$ & $6.4 c$ \\
\hline & \multicolumn{12}{|c|}{ Straw } \\
\hline$V_{1}$ & $10 \mathrm{c}$ & $52 \mathrm{c}$ & $55 \mathrm{c}$ & $0.21 \mathrm{c}$ & $1.63 \mathrm{a}$ & $1.70 \mathrm{a}$ & $0.02 \mathrm{c}$ & $0.04 b$ & $0.07 a$ & $8.2 \mathrm{c}$ & $8.7 \mathrm{~b}$ & $8.1 \mathrm{c}$ \\
\hline$V_{2}$ & $40 \mathrm{a}$ & $75 \mathrm{a}$ & $82 \mathrm{~b}$ & $0.93 b$ & $1.35 \mathrm{c}$ & $1.40 \mathrm{~b}$ & $0.05 \mathrm{a}$ & $0.06 a$ & $0.08 a$ & $9.1 \mathrm{a}$ & $9.4 \mathrm{a}$ & $9.7 \mathrm{a}$ \\
\hline$v_{3}$ & $10 \mathrm{c}$ & $62 b$ & $97 \mathrm{a}$ & $1.58 \mathrm{a}$ & $1.60 \mathrm{~b}$ & $1.70 \mathrm{a}$ & $0.03 \mathrm{bc}$ & $0.05 a b$ & $0.07 a$ & $8.5 b$ & $8.6 \mathrm{~b}$ & $8.6 \mathrm{~b}$ \\
\hline \multirow[t]{2}{*}{$V_{4}$} & $15 \mathrm{~b}$ & $42 \mathrm{~d}$ & $52 d$ & $0.08 d$ & $0.35 \mathrm{~d}$ & $1.20 \mathrm{c}$ & $0.04 a b$ & $0.04 b$ & $0.05 b$ & $7.1 \mathrm{~d}$ & $7.1 \mathrm{c}$ & $7.3 \mathrm{~d}$ \\
\hline & \multicolumn{12}{|c|}{ Translocation from straw to grains (\%) } \\
\hline$V_{1}$ & $8.82 b$ & $34.61 \mathrm{a}$ & $36.36 a$ & $66.66 \mathrm{a}$ & $25.15 d$ & $35.88 d$ & $50.00 \mathrm{c}$ & $75.00 \mathrm{a}$ & $71.42 \mathrm{c}$ & $81.20 d$ & $91.95 a$ & $97.53 a$ \\
\hline$V_{2}$ & $20.00 d$ & $25.33 b$ & $29.26 c$ & $12.90 \mathrm{~d}$ & $84.88 a$ & $55.71 b$ & $60.00 \mathrm{~b}$ & $66.66 \mathrm{~b}$ & $75.00 \mathrm{~b}$ & $90.10 a$ & $90.42 \mathrm{c}$ & $92.78 b$ \\
\hline$V_{3}$ & $90.00 \mathrm{a}$ & $17.74 \mathrm{c}$ & $21.64 d$ & $18.35 \mathrm{c}$ & $28.75 \mathrm{c}$ & $54.70 \mathrm{c}$ & $66.66 a$ & $66.66 \mathrm{~b}$ & $71.42 \mathrm{c}$ & $87.05 \mathrm{c}$ & $90.69 \mathrm{~b}$ & 88.37c \\
\hline $\mathbf{V}_{4}$ & $40.00 \mathrm{c}$ & $33.33 a$ & $34.61 \mathrm{~b}$ & $62.50 \mathrm{~b}$ & $71.42 b$ & $79.16 \mathrm{a}$ & $25.00 d$ & $50.00 \mathrm{c}$ & $80.00 \mathrm{a}$ & $87.32 b$ & $88.73 d$ & $87.67 d$ \\
\hline
\end{tabular}

Data in Table (5) indicate that the barley varieties generally had the lowest content of studied heavy metals under all water treatments. No significant in $\mathrm{Cd}$ for all treatments of water quality and barley varieties. V2 variety had the lowest content of $\mathrm{Pb}, \mathrm{Ni}$ and $\mathrm{Cu}$ under all water treatments. The order of barley varieties to concentration of heavy metals decreased as follow:

With Cd: $v_{1}<v_{2}<v_{3}<v_{4}$

With $\mathrm{Pb}: \mathrm{v}_{4}<\mathrm{v}_{1}<\mathrm{v}_{3}<\mathrm{v}_{2}$

With $\mathrm{Cu}: \mathrm{v}_{1}<\mathrm{v}_{2}<\mathrm{v}_{3}<\mathrm{v}_{4}$

With $\mathrm{Ni}: \mathrm{v}_{2}<\mathrm{v}_{1}<\mathrm{v}_{3}<\mathrm{v}_{4}$

These results very important for classified the common barley varieties to various heavy metals polluted soils. From these sequences we can favor one variety in every soil polluted with one element.

These results are in partial agreement with those obtained by Zein et al. (1996) in their study on soybean cultivars. These results may be due to the differences in genetic constitution of the studied genotypes and / or the dilution effect phenomenon. This conclusion is in partial agreement with that of Shalaby et al. (1996) who concluded that increasing of heavy metals concentration in plants may attributed either to the higher amounts of these heavy metals added into the used soil through the applied wastes.

Translocation coefficient from straw to grains:

Once the ions have been absorbed through the grains and have been transferred to the xylem vessels, there is possibility of movement throughout the whole plant, the rate and extent of movement within plants was studied by, Alloway (1995). The data of heavy metal concentration in 
Atwa. A. A. E. et al.

seeds, straw, of studied barely varieties and coefficient of their translocation (TC\%) from straw to seed are presented in Table 5 and seed TC was calculated as follows.

Content of heavy metal in grains $(\mathrm{mg} / \mathrm{kg})$

\section{Grains TC \% = Content of the same heavy metal in straw $(\mathrm{mg} / \mathrm{kg})$}

$\times 100$

Data in Table (5) illustrate that the studied heavy metals translocation from sraw to grains can be arranged according to mean values of translocation coefficient in the following decreasing order:

$\mathrm{Cd}>\mathrm{Cu}>\mathrm{Ni}>\mathrm{Pb}$

It shows that $\mathrm{Cd}$ was the largest values of $\mathrm{TC} \%$ while $\mathrm{Pb}$ was the least in translocation from sraw to grains in all types of water treatments $\left(W_{1}, W_{2}\right.$ and $\left.W_{3}\right)$. The results are in good agreement with those of Zein et al. (2002) and Chaney and Giordano (1977) who classified Pb as one of the least translocated elements with plant. They added that, under conditions of optimal growth, pb precipitates on root cell wall in the insoluble amorphous form. Zhen - Guo Shen et al., (2009). found that application of EDTA ( as an organic conditioner ) to the soil significantly increased the concentrations of $\mathrm{Pb}$ and enhancing $\mathrm{Pb}$ accumulation in the plants while the $\mathrm{Cu}, \mathrm{Cd}$ and $\mathrm{Ni}$ concentration and translocation coefficient indicate that $\mathrm{Ni}$ values increased due to drainage water treatment than other treatment due to its higher content of polluted drainage water from oil and soap factory ( used $\mathrm{Ni}$ as a catalyst in one processes of manufacturing). The obtained results are in good agreement with that of (Zein et al., 2012) and Chancy and Giordano (1977) for heavy metal translocation

\section{Conclusion}

Considering the previous discussions and conclusions, it seems that there is an obvious need for more research work to be carried out on the risk assessment of heavy metals contaminated soils. As mentioned by Eissa and El-Kassas (1999) the danger of distribution wastes by such factories containing high concentration of heavy metals affects the survival in the suffering areas. The safest policy would appear to minimize inputs of heavy metals to soil wherever to save our life and economy and restrict heavy metals bioavailability in the soil - plant animal pathway. Abo El-Naga et al. (1999) and Zien et al.(1998 and 2009) recommended that attention must be earnestly given to protect the environment and commitments and the latest law issued 1994 in Egypt, must be obligatory under taken for these factories to prevent them from polluting agricultural soil by wastes. They added that apart from the roles played by pollution control and soil chemistry, plant breading can make a vital contribution through the selection and utilization of crop genotypes which accumulate the least heavy metals 


\section{REFERENCES}

Abdullahi, M. S., A.Uzairu and O. J.Okunola (2009). Quantitative Determination of Heavy Metal Concentrations in Onion Leaves Int. J. Environ. Res., 3(2):271-274.

Abo El-Naga, S.A; M. M.El-Shinawani; M.S. El-Swaaby and M.S. Salem (1999). Chemical pollution of soils, water and plants at the industrial area of Helwan city in Egypt. J. Soil Sci. 39 (3): 263.

Aboulroos, S.A.; Sh. Sh. Halah; M.I. El-kherbawy and E.H. Badawy (1991). Fractionation of some heavy metals in soils irrigated with sewage effluents for different years. Egypt. J. Soil Sci. 31 (1), 43.

Kabata-Pendias A. (2000). "Trace elements in soils and plants". $3^{\text {rd }}$ edn. CRC, Florida.

Alloway. B. J. (1995). Heavy metals in soils, $2^{\text {nd }}$ Chapman and Hall London

Boussamo, N.; O.O. Uariti ; A.Suzuki and M.H. Ghorbal (1999). Cadmium stress on nitrogen assimilation. Journal of plant physiology.155: $310-$ 317.

Chaney, R. L. and R. L. Giordano (1977). Solis for the management of organic wastes and waste water, In : L.F. Elliot and F.J. Steven son (Eds.) Soil Sci. Soc. Am., Am, Soc. Agron 7 Crop Sci. Soc. Am., Madison. 235-279 (C.F Alloway, 1995).

Chapman, H. D and P. E. Pratt (1961). Method of analysis for soils, plants and waters. Univ. California; Division of Agric. Science.

Cunningham, L.M.; F.W. Collins and T.C. Hutchinson (1975). Physiological and biochemical a speets of cadmium toxicity in soybean, paper presented at Int. Conf. on heavy metals in the Environmental, Toronto P. 97.

Devkota ,B., and G.H.Schmidt(2000). Accumulation of heavy metals in food plants and grasshoppers from the Taigetos Mountains, Greece Agric.Ecosyst.Environ.78, 85 -91

Duncan,B.D.(1965). Multiple range and multpe F-test Biometrics, 11;1-42.

Duneman, L., N. Von Wiren; R. Schulz and H. Marschener (1991). Plant and Soil, 133, 263.

Eissa, A.M. and H.I. El-Kasses (1996). Impact of heavy metals on soil, plant and water at Abou-Zaabal area. Egypt. J. soil Sci. 39 (2), 211.

El-Mowelhi, N.M; B.M. El-Nasher and A.F. El-wakel (1995). Quality aspects of the drainage water of western delta area. Conf. of on farm irrig. And Agro climatology, Cairo, Egypt pp. 638.

El-Sanafawy, Hamida, M. (2002). Geochemical investigation on soil and water on polluted areas in Mid-Nile Delta for environmental assessment. Ph.D Thesis, Fac. Sci. Mansoura Univ., Egypt, p. 248.

FAO (1989). Water quality for agricultural. In R.S. Ayears and D.W. Westcot. Irrigation and Drainage paper 29 Rev. 1, Rome.

Ferguson.E.J.,(1990)Heavy metals in plants .In:Ferguson,E.J.(Ed), The Heavy Elements, Chemistry, Environmental Impact and Health Effects. Pergamon Press, Oxford, UK,pp7-30. 
Atwa. A. A. E. et al.

Frost,H.L.. and L.H.Ketchum (2000). Trace metal concentration in durum wheat from application of sewage sludge and commercial fertilizer.Adv.Environ.Res.4,347-355.

Hart, J. J., R. M. Welch, W. A. Novell, L. A. Sulivan and L. V. Kochian (1998). Characterization of cadmium binding, uptake , and translocation in intact seedlings of bread and durum wheat cultivars .plant physiology.116:1413 -1420 .

Lake,D.L., P.W.W.Kirk and J.N. Lester(1984). The fractionation, characterization and speciation of heavy metals in sewage sludge and sewage sludge amended soils.:areview.J.Environ.Qual.13,175-183.

Kabata-pendias A. and H. pendias (1992). Trac elements in soil and plants 2 ${ }^{\text {nd }}$ Ed.CRC press, BocaRoton, flo (C.F. Alloway, 1995).

Lindsay, W.K. and W.A. Norvell (1978). Development of a DTPA test for zinc, iron, manganese and Copper. Soil, Sci. Soc. Amer. J. Proc, 42 : 421-428.

Omar, E.H.; E.A.E. Gazia, M.A; Ghazy and M.A.A. Abd Allah (2001). Effect of irrigation water quality and sludge application on soil salinity, sugarbeet and canola yield and irrigation efficiencies. Minufiya J. Agric. Res. Vol. 26 No. 6: 1751-1665.

Page, A.L.; F.T. Bingham and A. C. Chang (1981). Effect of heavy metals pollution on plants Vol. 1, $1^{\text {st }}$ lepp, N.W. Applied science, London pp. 72-109.

Richards, L.A. (1969). Diagnosis and Improvement of Saline and Alkali Soils. U.S. Dep. Agric. Handbook No. 60.

Shalaby. M.H; O.A Gabran and M.I. Raslan (1996). Chemical properties of soils as affected by pollution of different wastes, J. Soil. Sci.36 (1-4) 1. 23.

Soudek P., A. Katrusáková , L. Sedlácek, S. Petrová , V. Kocí , P. Marsík, M. Griga , T. Vanek ( 2010). Effect of heavy metals on inhibition of root elongation in 23 cultivars of flax (Linum usitatissimum L.). Arch Environ Contam Toxicol. 2010 Aug;59(2):194-203. Epub 2010 Feb 20.

Voutsa,D., A.Grimanis and C.Savora(1996). Trace elements in vegetables in an industrial area in relation to soil and air particulate matter.Environ.pollut.94,325 -335.

Zein, F. I.; Hamida M.A. El-Sanafawy; N.I. Talha and Samia A. Salama (2009). Using canola plants for phytoextracting heavy mateals from soil irrigation with polluted drainage water for Alongterm. J. Agric. Sci. Mansoura Univ., 34 (6): 7309-7323.

Zein, F. I.; N.I. Talha; Hamida M.A. El-Sanafawy; and I.A. El-Saiad (2012). Heavy metals content of some cotton genotypes and soil properties as affected by water quality. J. Agric. Sci. and Agric. Eng., Mansoura Univ., Vol. 3 (12): 1125-1136.

Zein, F. I; A.A El-Leithi and M. Z Abou Amou. (1996). Effect of irrigation with polluted drainage water on clay soils, some crops and their contents of heavy metals, some soybean cultivars. J. Agri-Sci-Mansoura Univ. 21 (10), 3753. 
Zein, F.I.; Maani, Z. Abou Amou, A.A. El-Leithi and M.M. El-Shami (2002). Effect of polluted irrigation water on some crops and their contents of heavy metals. 1-Wheat. Egypt. J. Soil Sci., 42 No. 1, PP. 139-159.

Zein, F.I.; O.A. Hegab and Hamida M. El-Sanafawy (1998). Geochemical studies on some polluted soils in Kafr El-Sheikh Governorate. Egypt. J. Agric. Sci. Mansoura Univ., Vol. 23, No. 6, PP. 2887-2918.

Zhen-Guo Shen, Xiang-Dong Li, Chun-Chun Wang, Huai-Man Chen and Hong Chua (2009). Lead phytoextraction from contaminated soil with high-Biomass plants Species. J. Environ. Qual. 31: 1893-1900.

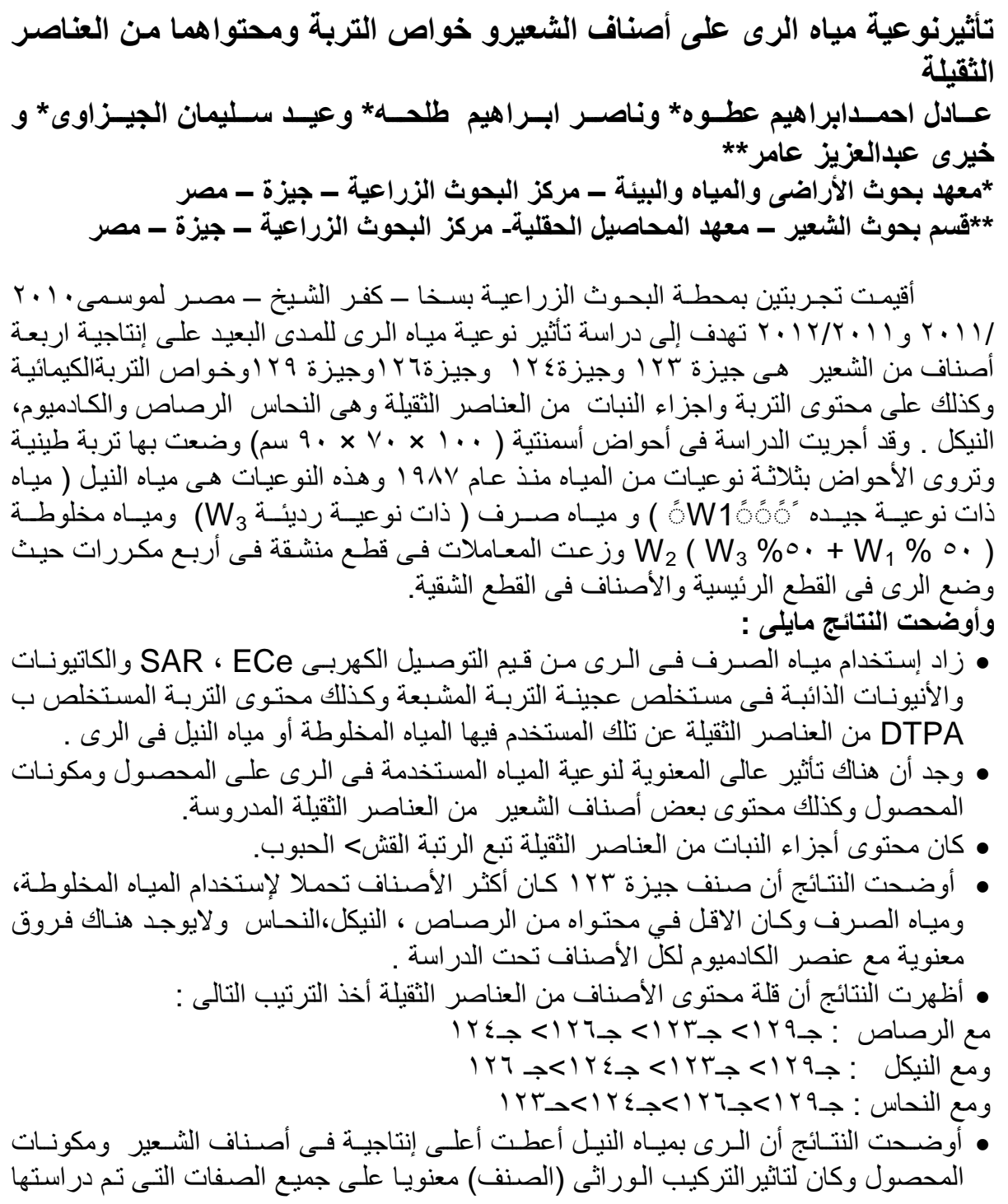




\section{Atwa. A. A. E. et al.}

خلال موسمى الزراعية وتفوق جيزة ج ب اعلى بـاقى الاصناف فى معظم الصفات التى تم

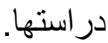

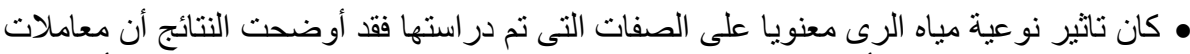

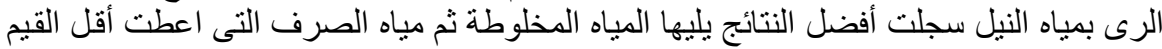

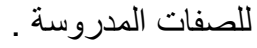
• كان تاثير التفاعل بين التركيب الور اثى ونو عية مياه الرى معنويا على الصفات التى التى تم دراستها

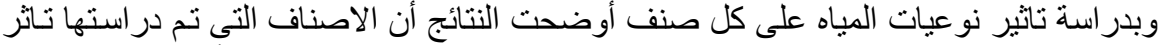

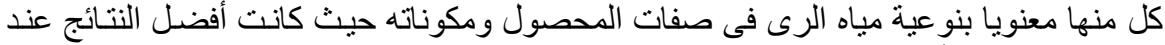

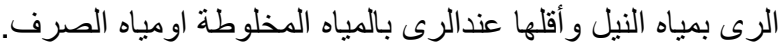

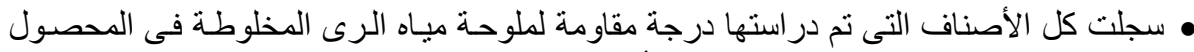

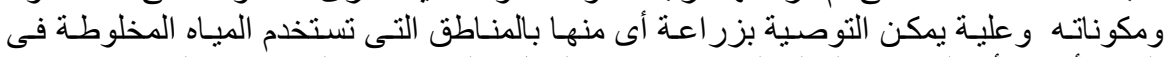

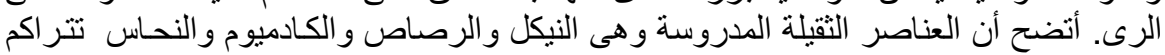

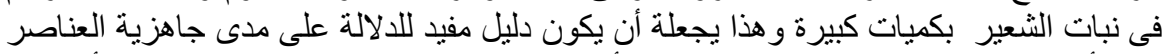

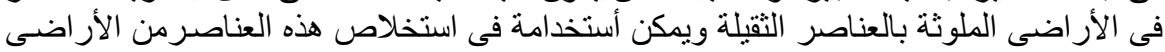

كلية الزراعة - جامعة المنصورة مركز البحوث الزراعية
قام بتحكيم البحث

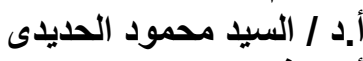

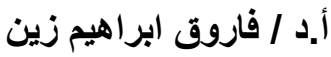

